\title{
Maternal Profile and Neonatal Outcomes of Pregnant Women Infected with HIV / AIDS in Banda Aceh on 2017-2019
}

\author{
Cut Meurah Yeni ${ }^{1}$, Riza Sufriadi ${ }^{2}$ \\ ${ }^{1}$ Department of Obstetrics and Gynecology of RSUDZA, Faculty of Medicine, Universitas Syiah \\ Kuala, Banda Aceh, Indonesia \\ ${ }^{2}$ Obstetrics and Gynecology Specialist Education Program of RSUDZA, Faculty of Medicine, \\ Universitas Syiah Kuala, Banda Aceh, Indonesia \\ E-mail: cutyeni65@gmail.com
}

\begin{abstract}
:
This aims of the study is to find out Profile of Maternal and Neonatal Outcomes in Pregnant woman Infected by HIV/AIDS. This research is a descriptive study, looking at maternal characteristics and infant outcomes of pregnant women infected with HIV / AIDS in RSUDZA. Based on the author's research on maternal profile and neonatal outcomes in pregnant women infected with HIV / AIDS in Banda Aceh, there were 14 cases during 20172019. There were 1 babies born with low birth weight, 1 stillbirth, 10 out of 14 vigorous babies, 10 cesarean births, 3 preterm births and 8 patients with no known CD4 + status.
\end{abstract}

Keywords:

maternal; neonatal; pregnant woman; HIV / AIDS

\section{Introduction}

One of the indicators of public health is through the Maternal Mortality Rate (MMR). Maternal Mortality describes the number of mothers who died from a cause of death related to pregnancy disorders or their handling (excluding accidents or incidental cases) during pregnancy, childbirth and in the puerperium (42 days after giving birth) regardless of the length of pregnancy per 100,000 live births. This indicator is not only able to assess maternal health programs, moreover it is able to assess the degree of public health, because of its sensitivity to improving health services, both in terms of accessibility and quality. Maternal deaths often occur due to complications that occur around the time of delivery, so the intervention is emphasized in the safe delivery of assistance by health workers who are trained and carried out in health facilities. Through good and correct help, it is hoped that complications resulting from mishandling can be prevented, knowing quickly the complications that arise and by immediately providing help including referring when needed. (Novita 2020)

Human immunodeficiency virus (HIV) is a retrovirus that infects cells of the immune system, destroys or damages its function. Viral infection results in progressive damage to the immune system, which leads to "immune deficiency." The immune system is considered deficient when it can no longer fulfill its role against infection and disease (WHO, 2019).

HIV continues to be a major global public health problem, so far it has claimed more than 35 million lives (WHO, 2018). The UNAIDS Global HIV Epidemic Report in 2012 showed that the number of HIV sufferers in the world reached 34 million people (Indonesian Ministry of Health, 2015). In 2017, 940,000 people died due to HIV-related causes globally. There are around 36.9 million people living with HIV at the end of 2017 with 1.8 million becoming newly infected in 2017 globally. There are around $59 \%$ of adults, $50 \%$ of whom are women and 2.1 million children aged less than 15 years (WHO, 2018). In South and Southeast 
Asia there are around 4 million people with HIV and AIDS (Aquired Immune Deficiency Syndrome). According to the WHO / SEARO Progress Report on HIV and AIDS 2011, in Southeast Asia there are around 1.3 million people (37\%) women infected with HIV. The number of women infected with HIV from year to year is increasing, along with the increasing number of men who have unprotected sexual relations, which in turn they transmit to other sexual partners. UNAIDS / WHO estimation data (2009) also estimated that 22,000 children in the Asia-Pacific region were infected with HIV and without treatment, half of the infected children died before the age of 2 years (Ministry of Health of the Republic of IndonesiaUnicef, 2015). Estimated results in 2012, in Indonesia there were 591,823 people with HIV positive and spread throughout the province. From the Monthly Report on HIV and AIDS Care in Indonesia up to November 2014, there were 49,217 PLHIV who received ARV therapy from 34 provinces and 300 districts / cities (Ministry of Health, Republic of Indonesia, 2015).

Neonatal HIV infection is the result of transmission from the mother to the unborn fetus, or during the intrapartum period, or secondary postpartum after breastfeeding. In the United States, perinatal transmission has been reduced to less than $1 \%$ in many countries, reflecting the adoption of major interventions during pregnancy, including starting ART to reduce viral load below detection rates and avoiding breastfeeding during the postpartum period (Rimawi, 2016). A recent study from Byrne stated that overall, only one baby was known to be diagnosed with HIV (PCR positive at $\leq 72$ hours), whose mother had acquired HIV perinatally. (Laura Bryne, et al, 2017).

Epidemiological data on neonatal outcomes born to mothers suffering from HIV / AIDS because in Indonesia is not widely known, including data in Aceh there is no adequate data collection. Therefore, researchers are interested in conducting research on maternal profiles and neonatal outcomes in pregnant women infected with HIV / AIDS in Banda Aceh.

\section{Review of Literatures}

\subsection{Human Immunodeficiency Virus}

Human immunodeficiency virus (HIV) is a retrovirus that infects cells of the immune system, destroys or damages its function. Viral infection results in progressive damage to the immune system, which leads to "immune deficiency". The immune system is considered deficient when it can no longer fulfill its role against infection and disease (WHO, 2019). The HIV virus is found in bodily fluids, especially in blood, sperm, vaginal fluid, and breast milk. The virus damages the human immunity and results in a decrease or loss of endurance so that it is easily infected by infectious diseases (Katiandagho, 2015).

As a result of decreased immunity the person is very susceptible to various infectious diseases (opportunistic infections) which are often fatal. HIV sufferers need antiretroviral (ARV) treatment to reduce the amount of HIV virus in the body so it does not enter the AIDS stage, while AIDS sufferers need ARV treatment to prevent opportunistic infections with various complications (Infodatin, 2015).

\subsection{Epidemiology}

HIV continues to be a major global public health problem, so far it has claimed more than 35 million lives (WHO, 2018). There are around 36.9 million people living with HIV at the end of 2017 with 1.8 million becoming newly infected in 2017 globally. There are about 
$59 \%$ of adults, about $50 \%$ of whom are women and 2.1 million children under the age of 15 years. (WHO, 2018). HIV / AIDS sufferers are estimated at 16 million women and 3.2 million children aged less than 15 years. The number of new HIV infections in 2013 was 2.1 million consisting of 1.9 million adults and 240,000 children aged less than 15 years. The number of deaths due to AIDS was 1.5 million consisting of 1.3 million adults and 190,000 children aged less than 15 years. (Infodatin, 2015). According to the WHO / SEARO Progress Report on HIV and AIDS 2011, in Southeast Asia there are around 1.3 million people (37\%) of women infected with HIV (WHO, 2019).

In Indonesia, HIV AIDS was first discovered in the province of Bali in 1987. Until now HIV AIDS has spread to 386 districts / cities in all provinces in Indonesia. Various countermeasures have been made by the Government in collaboration with various institutions in the country and abroad. The following shows the situation of HIV AIDS sourced from the Directorate General of PP-PL through the Application of the Information System for HIV-AIDS and STI (SIHA) (Infodatin, 2015).

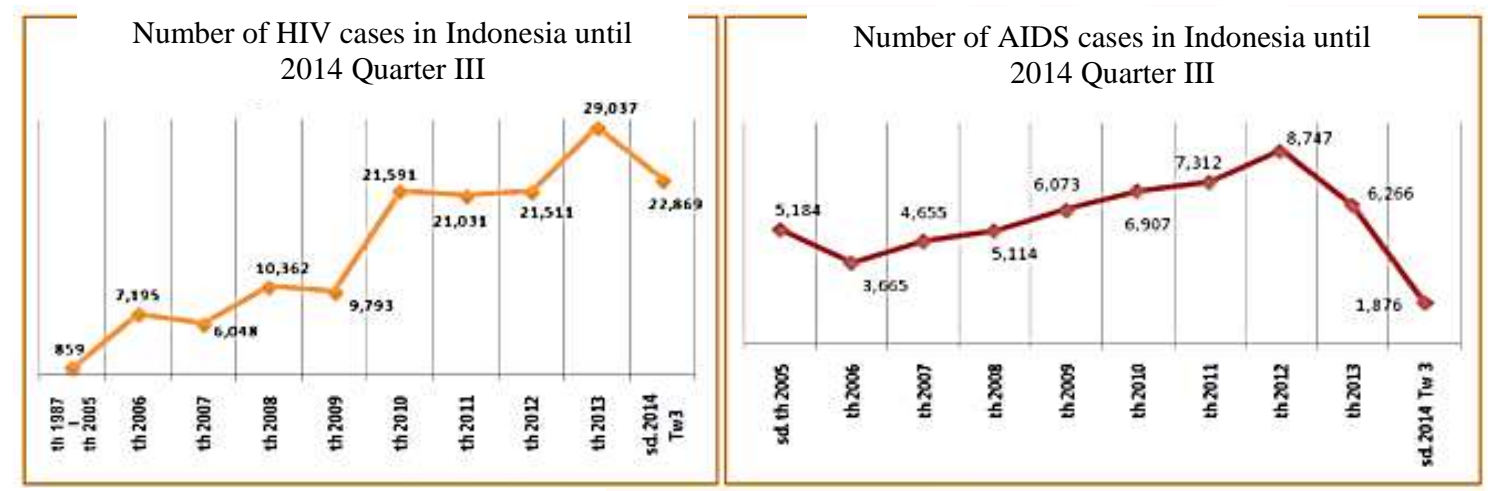

Source: Ditjen PP \& PL, Kemenkes RI, 2014

\subsection{Pathophysiology}

As a single stranded ribonucleic acid (RNA) retovirus, HIV has the ability to infiltrate deoxiribonucleic acid (DNA) so that it will enter host cells. The virus will integrate into the host cell so that the virus has the potential to transcribe when the host cell mutates the cell. The process of mutation of cells that have been infected with the HIV virus causes replication of the HIV virus continues to occur and produce strains that are resistant to the host immune system and anti-retoviral therapy (Queenan T, 2015).

The main cause of the spread of HIV is through sexual relations. The HIV virus consists of two strains, HIV-1 and HIV 2. The most common cause is the HIV-1 strain (Cunningham, 2018). HIV infects T lymphocytes that produce CD 4 antigens, thereby causing CD 4 cell loss and damage to the cellular and humoral immune systems. When there is a decrease in CD 4, it allows the virus to develop progressively so as to produce AIDS which is characterized by opurtunistic infections (Berghella, 2017)

The incubation period from exposure to clinical symptoms averages 3 to 6 weeks. Acute HIV infection is similar to other viral syndromes that appear less than 10 days. Common symptoms include fever, weakness, headache, lymphadenopathy, myalgia, nausea and others. After the acute symptoms are over, viremia usually decreases to a point and patients with high virus rapidly develop AIDS (Cunningham, 2018).

\subsection{Neonatal Transmission and Prevention Measures}

Neonatal HIV infection is the result of transmission from the mother to the unborn 
fetus, or during the intrapartum period, or secondary postpartum after breastfeeding. In the United States, perinatal transmission has been reduced to less than 1\% in many countries, reflecting the adoption of major interventions during pregnancy, including starting ART to reduce viral load below detection rates and avoid breastfeeding during the postpartum period. (Rimawi, 2016).

Globally, without intervention, cumulative HIV transmission rates in utero, intrapartum and postpartum are around $35-40 \%$ (Kourtis A. P., 2006). In the breastfeeding population, postpartum HIV transmission through breastfeeding contributes around $40-45 \%$ of all mother-to-child transmission. Maternal HIV viral load levels are by far the most predictive factor for perinatal HIV transmission. Higher HIV viral load correlates with a greater risk of perinatal transmission, although transmission can occur with any viral load, even when systemic plasma viral load is below the detection level (Ioannidis J. P. A., 2001). Rates of transmission for HIV can be reduced to less than $1 \%$ in pregnant women who adhere to their ART with virologic suppression and other perinatal recommendations (Rimawi, 2016).

The Government of the Republic of Indonesia through the Ministry of Health organizes a Prevention of Mother to Child HIV (PPIA) Program or Prevention of Mother-toChild HIV Transmission (PMTCT) is a very effective intervention to prevent transmission. This effort is integrated with efforts to eliminate congenital syphilis, because syphilis increases the risk of HIV transmission as well as causing various health problems in the mother and is also transmitted to infants such as HIV infection. In efforts to prevent transmission of HIV and syphilis from mother to child, PPIA services and prevention of congenital syphilis are integrated with maternal and child health services $(\mathrm{MCH})$. This is done through integrated antenatal services both at the first level and referral health facilities. To increase the coverage and services of PPIA, the Ministry of Health has carried out several activities, including: i) developing health service facilities that can provide PPIA services; ii) improvement of clinical abilities through TOT facilitators and training for health workers; and iii) preparation of manuals for the prevention of transmission of HIV and Syphilis from Mother to Child for health workers in government and non-government health facilities (Ministry of Health of the Republic of Indonesia-Unicef, 2015).

The overall aim of the PPIA Program is to prevent transmission of HIV and syphilis from mother to child and improve the quality of life of mothers and children infected with HIV and syphilis in order to reduce the incidence of new cases of HIV in infants and the incidence of congenital syphilis. (Ministry of Health of the Republic of Indonesia-Unicef, 2015). The specific objectives are as follows:

a. Prevent the occurrence of new cases of HIV in infants and the occurrence of congenital syphilis through prevention of HIV transmission and syphilis from mother to child.

b. Increase the survival of mothers and children due to HIV / AIDS and / or syphilis as low as possible, especially in areas with widespread and concentrated HIV epidemics.

c. Improve the quality of life of pregnant women and children with HIV and syphilis. (Ministry of Health of the Republic of Indonesia-Unicef, 2015)

\subsection{HIV Diagnosis during Pregnancy}

Screening tests are positive with traditional HIV testing modalities, either with a $1 / 2$ HIV Antigen / Antibody test or with a Fourth Generation test which basically determines the diagnosis of HIV infection. Newer testing modalities include the HIV Multispot test, which includes a rapid joint HIV-1 / HIV-2 test to distinguish between HIV-1 and 2 infections; hence, a positive Multispot test confirms the diagnosis of HIV. However, if the Multispot test is negative, additional tests to confirm the diagnosis of HIV infection include continuing with 
the polymerase chain reaction (PCR) test. The sensitivity and specificity of HIV testing rapidly approaches $100 \%$, while the positive predictive value (PPV) depends on the prevalence of the disease in the general population tested. In populations where HIV prevalence is low, lower PPV is noted (Rimawi, 2016).

\subsection{Effects of HIV and Pregnancy}

The effect of pregnancy on HIV in general there is no clear influence on the development of HIV. A temporary reduction in CD4 $+\mathrm{T}$ lymphocytes is not clinically significant. Effects of HIV on pregnancy: Perinatal transmission can occur antepartum $(25 \%$ $40 \%)$, intrapartum $(60 \%-75 \%)$, or postpartum with breastfeeding (14\%). Perinatal transmission is closely related to viral load. There is a strong correlation between maternal high viral load at delivery and the risk of transmission, but transmission has occurred at all levels of viral load. Transmission rates are around $1.2 \%$ on ART, $10.4 \%$ on AZT monotherapy, and 25\% on without ARVs. (Berghella, 2017).

\subsection{Efek ARV pada Neonatal}

Larger cohort studies in sub-Saharan Africa involved more than 3000 patients for their association with adverse pregnancy outcomes, specifically for preterm birth, Small Gestational Age (SGA), and low birth weight (LBW) in relation to the duration of ARV exposure. The researchers found a 30\% increase in the risk of preterm birth in women exposed to antiretroviral drugs, with a $20 \%$ increase in the risk of preterm births for women who started ARVs before conception compared with those who started ARVs during pregnancy or received zidovudine monotherapy. It is unclear the exact mechanism why this adverse neonatal output occurs, and further comparative evaluation of different ARV regimens is needed. This may actually be due to the severity of the disease, rather than the relationship with ARVs (Rimawi, 2016).

\subsection{Childbirth Method}

The method of delivery is considered based on the amount of viral load. Women with a viral load $>1000$ copies / $\mathrm{mL}$ are considered for searean section at 38 weeks' gestation with perioperative addition with intravenous Zidovudine to maximize prevention of perinatal transmission. In cases where a viral load of less than 1000 copies / $\mathrm{mL}$ does not obtain additional benefit from cesarean section, cesarean section is considered based on obstetric indications. ART should be continued throughout the labor process (Berghella, 2017).

\section{Research Methods}

This research is a descriptive study, looking at maternal characteristics and infant outcomes of pregnant women infected with HIV / AIDS in RSUDZA. The study was conducted in January 2019. The research method used was a cross-sectional study, taking samples from RSUDZA medical records. The population in this study were all pregnant women who were diagnosed with HIV / AIDS in Aceh. The sampling method is total sampling that is all pregnant women with HIV / AIDS infection who deliver at RSUDZA in the period January 2017 to August 2019 both in vaginal delivery and cesarean section. All pregnant women with HIV / AIDS who must meet the inclusion and exclusion criteria. The inclusion criteria in this study are

1. Pregnant women with HIV / AIDS infection with laboratory results

2. Childbirth in RSUDZA in the 2017-2019 period.

Exclusion Criteria:

1. Pregnant women with HIV who are treated but do not give birth at RSUDZA 


\section{Discussion}

\subsection{Result}

This research was conducted at RSUDZA by using secondary data from the Medical Record File. Based on data collection of childbirth patients with HIV / AIDS infections that have been conducted at RSUDZA from January 2017 to August 2019, the data obtained amounted to 14 people.

\section{a. Baby Birth Weight}

Table 1. Frequency Distribution of Birth Weight of Babies born to neonates produced by mothers with HIV / AIDS

\begin{tabular}{llll}
\hline No & Baby Weight & Frequency (n) & Percentage (\%) \\
\hline 1. & $<2500$ gram & 2 & 14,28 \\
2. & $\geq 2500-4000$ gram & 12 & 85,71 \\
\hline 3 & $\geq 4000$ gram & 0 & 0 \\
\hline & Total & 14 & 100 \\
\hline
\end{tabular}

Based on table 1 above, it can be seen from the results of the study that 2 patients $(14.28 \%)$ were born with birth weight less than 2500 grams, 12 babies were born with birth weight more than 2500 grams and no babies were born with macrosomia (more than 4000 gram).

\section{b. Score Report}

Table 2. Distribution of Asphyxia Frequencies in Neonates produced from mothers infected with HIV / AIDS

\begin{tabular}{llcc}
\hline No. & APGAR & Frequency (n) & Percentage (\%) \\
\hline 1. & APGAR 0-3 & 1 & 7,14 \\
\hline 2. & APGAR 4-6 & 3 & 21,433 \\
\hline 3. & APGAR 7-10 & 10 & 71,42 \\
\hline & Total & $\mathbf{1 4}$ & $\mathbf{1 0 0}$ \\
\hline
\end{tabular}

Percentage Based on table 2 above, it can be seen from the results of the study that 1 patient (7.14\%) was born with an Apgar score below 3, 3 patients $(21.43 \%)$ were born with an APGAR score of 4-8 (moderate asphyxia) and there were 10 infants $(1071.42 \%)$ born with APGAR 7-10 (vigorous baby).

\section{c. Childbirth Method}

Table 3. Frequency Distribution Mode of delivery in neonates produced from pregnant women infected with HIV / AIDS

\begin{tabular}{llll}
\hline No & How to give birth & Frequency $(\mathbf{n})$ & Percentage $\mathbf{( \% )}$ \\
\hline 1. & Pervaginam & 4 & 28,57 \\
2. & Caesarean section & 10 & 71,43 \\
\hline & Total & 14 & 100 \\
\hline
\end{tabular}

Based on table 3 above, it can be seen from the results of the study that 4 patients $(28.57 \%)$ were born vaginally and 10 patients $(71.43 \%)$ were born by cesarean section. 


\section{d. Age of gestation}

Table 4. Distribution of Age Frequency Content in neonates produced from mothers with HIV / AIDS

\begin{tabular}{|c|c|c|c|}
\hline No & Age of Pregnancy & Frequency (n) & Percentage $(\%)$ \\
\hline 1. & $<37$ week & 3 & 21,43 \\
\hline 2. & $>37$ week & 11 & 78,57 \\
\hline & Total & 14 & 100 \\
\hline
\end{tabular}

Based on table 4 above, it can be seen from the results of the study that 3 patients $(21.43 \%)$ were born at less than 37 weeks 'gestational age and 10 patients $(78.57 \%)$ were born at 37 weeks' gestation.

\section{e. Total CD4++}

Table 5. Frequency Distribution of CD4 + Cell Counts in women with HIV / AIDS who give birth in RSUDAZA

\begin{tabular}{|c|c|c|c|}
\hline No & Cell Count CD4+ & Frequency (n) & Percentage $(\%)$ \\
\hline 1. & $\leq 350 \mathrm{cell} / \mathrm{ml}$ & 4 & 28.57 \\
\hline 2. & $>350$ cell $/ \mathrm{ml}$ & 2 & 14,28 \\
\hline 3. & There is no data & 8 & 57,15 \\
\hline & Total & 14 & 100 \\
\hline
\end{tabular}

Based on table 5 above, it can be seen from the results of the study that 4 patients (28.57\%) were born from mothers infected with HIV / AIDS with CD4 + cell counts of more than 350 cells / $\mathrm{ml}$ of blood and 2 patients $(14.28 \%)$ with data on the number of CD4 + cells were less than 350 cells $/ \mathrm{ml}$ and there were 8 patients $(57.15 \%)$ for whom there were no CD4 + data.

\subsection{Discussion}

Based on the results of the study as many as 2 patients (14.28\%) were born with birth weight less than 2500 grams, 8 babies born with birth weight more than 2500 grams. The relationship of birth weight with maternal HIV status is still being debated. Some stated there was no relationship between birth weight of babies with HIV. But it has been previously reported that compared to children who are not exposed, children who have HIV exposure in the womb are more susceptible to stunting, birth weight, height and head circumference are generally lower than their unexposed peers. (McGrath CJ, 2012) However, it is still controversial for the effects of maternal HIV infection on LBW and premature birth. Brocklehurst et al. reported that increased risk of LBW and preterm birth was associated with maternal HIV infection. (Brocklehurst P, 1998). It was found that women in developing countries have a higher risk for LBW and premature births than in developed countries. A number of new studies in the meta-analysis also show that maternal HIV infection increases the risk of LBW and premature birth. (Xiao PL, 2015).

APGAR Output Scores in this study found that 1 patient $(7.14 \%)$ was born with an APGAR score below 3 of 3 patients $(21.43 \%$ ) born with an APGAR score of 4-6 (moderate asphyxia) and there were 10 babies born with APGAR 7-10 (vigorous baby). In Africa, a threefold increased risk of a very low Apgar score in live infants was observed for HIVinfected women treated compared to non-HIV-infected women for Apgar scores 1, 5 and 10 minutes). On exploratory possibilities by comparing the risk of early neonatal death roughly 
between low-minute first-minute Apgar babies being treated and untreated HIV-infected mothers. The results show that the risk of early neonatal death among those treated is half of women infected with HIV who are not treated. Compared with babies from caring for women infected with HIV, this risk is slightly increased for female infants with unknown HIV status, while it is similar to women who are not infected with HIV. Given the importance of Apgar scores in predicting neonatal survival, further studies are needed of the detrimental effects of HIV treatment on Apgar scores. (NA Habib, 2018).

Based on the results of the study as many as 4 patients $(28.57 \%)$ were born by vaginal and 10 patients $(71.43 \%)$ were born by cesarean section. The method of delivery is considered based on the amount of viral load. Women with a viral load $>1000$ copies / $\mathrm{mL}$ are considered for a secular section at 38 weeks' gestation with perioperative addition with intravenous Zidovudine to maximize the prevention of perinatal transmission. In cases where a viral load of less than 1000 copies / $\mathrm{mL}$ does not obtain additional benefit from cesarean section, cesarean section is considered based on obstetric indications. ART should be continued throughout the labor process. Scheduled maternal delivery that is carried out solely for the prevention of perinatal transmission in women receiving ART with an HIV viral load of $>1,000$ is not routinely recommended given the low rate of perinatal transmission. In women with an HIV RNA level of ,0001,000, cesarean delivery is performed on the basis of obstetric indications. In women whose viral load is unknown, the benefit of cesarean section is considered in preventing mother to baby transmission. (Berghella, 2017). But in women with HIV RNA>1,000 or unknown HIV viral load levels that come in spontaneous labor or with ruptured membranes, there is insufficient evidence to determine whether cesarean births reduce the risk of perinatal HIV transmission. For women taking antiretroviral therapy with an HIV viral load $\leq 1,000$, the duration of rupture of membranes was not associated with an increased risk of perinatal transmission, and vaginal delivery was recommended. (U.S. Department of Health and Human Services, 2018).

Based on table 4 above, it can be seen from the results of the study that 3 patients $(21.43 \%)$ were born at less than 37 weeks 'gestation and 11 patients $(78.57 \%)$ were born at 37 weeks' gestation. In contemporary practice when treating pregnant women with ART and monitoring viral load to assess the response of anti-viral. Women with a viral load of 1,000 or less elective delivery time before 40 0/7 weeks have not been shown to reduce the risk of mother-to-child. HIV viral load levels in pregnant women should be monitored at the first prenatal visit; 2-4 weeks after starting (or changing) ART drug regimens; monthly until the RNA level is not detected; and then at least every 3 months during pregnancy. Viral load should also be assessed at around $340 / 7$ to $360 / 7$ weeks of pregnancy to inform decisions about how to deliver and optimal care for newborns. HIV-infected pregnant women whose viral load is more than 1,000 at or near delivery, regardless of antiretroviral antepartum therapy, or whose levels are unknown, x [opl / jk ... should be counseled about the potential benefits of and offer cesarean delivery before gestational age $380 / 7$ weeks to reduce the risk of transmission from mother to child. In this situation, scheduling cesarean delivery at $380 / 7$ weeks is intended to reduce the possibility of labor or premature rupture of membranes. (ACOG, 2018).

Based on table 5 of the results of the study as many as 4 patients $(28.57 \%)$ were born from mothers infected with HIV / AIDS with a CD4 + cell count of more than 350 cells / ml of blood and 2 patients $(14.28 \%)$ with data on a CD4 + cell number less of 350 cells / $\mathrm{ml}$ and there were 8 patients $(57.14 \%$ ) for whom there were no CD4 + data. CD4 is the best parameter to measure immunodeficiency. If used in conjunction with clinical assessment, CD4 cell counts can be an early indicator of disease progression because CD4 cell counts fall earlier 
than clinical conditions. CD4 in this study sample, there were 3 patients in the range of moderate immunodeficiency and there were 2 patients with mild immunodeficiency. While 8 patients were unknown CD4 levels.

\begin{tabular}{|l|l|l|l|l|}
\hline \multicolumn{5}{|c|}{ WHO Classification of HIV Immunodeficiency Using CD4 } \\
\hline \multirow{3}{*}{ immunodeficient } & \multicolumn{4}{|c|}{ CD4 cell count according to age } \\
\cline { 2 - 5 } & $\begin{array}{l}\leq \%) \\
(11 \text { mount }\end{array}$ & $\begin{array}{l}12-35 \text { mount } \\
(\%)\end{array}$ & $\begin{array}{l}36-59 \text { mount } \\
(\%)\end{array}$ & $\begin{array}{l}5 \text { Years - Adult } \\
\text { (Cell/mm3) }\end{array}$ \\
\hline There is no & $>35$ & $>30$ & $>25$ & $>500$ \\
\hline Light & $30-35$ & $25-30$ & $20-25$ & $350-499$ \\
\hline Middle & $25-30$ & $20-25$ & $15-20$ & $200-349$ \\
\hline Heavy & $<25$ & $<20$ & $<15$ & $<200$ atau $<15 \%$ \\
\hline
\end{tabular}

WHO Classification Table on Immunodeficiency using CD4 (Indonesian Ministry of Health, 2015)

\section{Conclusion}

Based on the author's research on maternal profile and neonatal outcomes in pregnant women infected with HIV / AIDS in Banda Aceh, there were 14 cases during 2017-2019. There were 1 babies born with low birth weight, 1 stillbirth, 10 out of 14 vigorous babies, 10 cesarean births, 3 preterm births and 8 patients with no known CD $4+$ status.

\section{References}

ACOG. (2018). Labor and Delivery Management of Women With Human Immunodeficiency Virus Infection. Acog Comittee Opinion, 132(3), pp. 131-137.

Berghella , V. (2017). Maternal-Fetal Evidence Based Guidliness. Third ed. New York USA: CRC Press.

Brocklehurst P, F. R. (1998). The association between maternal HIV infection and perinatal outcome: a systematic review of the literature and meta-analysis.. BJOG, 105(8), p. $836-48$.

Cunningham, F. G. (2018). Williams obstetrics. New York: McGraw-Hill.

Dinkes Aceh, 2017. Profil Kesehatan Aceh, Banda Aceh: Dinas Kesehatan Aceh.

Infodatin. (2015). Situasi dan Analisis HIV/AIDS, Jakarta: Pusat Data Dan Informasi Kementerian Kesehatan RI.

Ioannidis J. P. A., A. E. J. A. A. e. a., (2001). Perinatal transmission of human immunodeficiency virus type 1 by pregnant women with RNA virus loads $<1000$ copies/mL. Journal of Infectious Diseases, 4(183), p. 539-545.

Katiandagho, D., (2015). Epidemiologi HIV-AIDS, Bogor:: In Media.

Kementerian Kesehatan RI, (2015). Lampiran Peraturan Menteri Kesehatan Republik Indonesianomor 87 Tahun 2014 Tentang Pedoman Pengobatan Antiretroviral. Jakarta: Kementerian Kesehatan RI.

Kementrerian Kesehatan Republik Indonesia-Unicef, (2015). Pedoman Manajemen Program Pencegahan Penularan HIV dan Sifilis dari Ibu ke Anak. Jakarta: Direktorat Jenderal Bina Kesehatan Ibu dan Anak Kementerian Kesehatan RI..

Kourtis A. P., L. F. K. A. E. J. J. D. J. B. M. (2006). Mother-to-child transmission of HIV-1: timing and implications for prevention. The Lancet Infectious Diseases, 6(11), p. 726-732. 
Laura Bryne, et al. (2017). Pregnancy incidence and outcomes in women with perinatal HIV infection. bindawi, 31 July, 31(23), p. 1745-1754.

McGrath CJ, N. R. R. B. (2012). The prevalence of stunting is high in HIV-1-exposed uninfected infants in Kenya. J Nutr, 142(4), p. 757-63.

NA Habib, e., (2018). Maternal HIV status and pregnancy outcomes in northeastern Tanzania: a registry-based study. BJOG, 1(epidemology), pp. 616-624.

Novita, W. (2020). The Relationship between Geography Access and Utilization of Basic Emergency Neonatal Obstetric Services (PONED) in Hamparan Perak Health Center, Deli Serdang Regency in 2018. Budapest International Research and Critics Institute-Journal (BIRCIJournal), p. 674-681

Queenan T, J., (2015). Protocols for Hirgh-risk Pregnancies: An Evidence-based Aproach. Sixth ed. West Sussex UK: John Wiley \& Sons.

Rimawi, B. H. H. L. B. M. L. \&. C. R., (2016). Management of HIV Infection during Pregnancy in the United States: Updated Evidence-Based Recommendations and Future Potential Practices.. PMC, 18 July, Issue Infectious diseases in obstetrics and gynecology, p. 2016: $7594306 .$.

U.S. Department of Health and Human Services, (2018). Recommendations for the Use of Antiretroviral Drugs in Pregnant Women with HIV Infection and Interventions to Reduce Perinatal HIV Transmission in the United States, New York: AIDSinfo.

WHO. (2018). HIV/AIDS, s.l.: WHO.

WHO.(2019). Definition of HIV, s.l.: World Health Organization Regional Oficer for South East Asia.

Xiao PL, Z. Y. C. Y. e. a., (2015). Association between maternal HIV infection and low birth weight and prematurity: a meta-analysis of cohort studies. BMC Pregnancy Childbirth, 15(oct), p. 246. 